\title{
Acute amiodarone interstitial toxicity presenting as unilateral pneumonitis
}

\author{
James Chen (10, ' Stephen Hinton ${ }^{1,2}$
}

${ }^{1}$ Department of General Medicine, St John of God Bunbury, Bunbury, Western Australia, Australia

${ }^{2}$ Rural Clinical School of WA, University of Western Australia, Perth, Western Australia, Australia

\section{Correspondence to}

Dr James Chen;

james.chen@health.wa.gov.au

Accepted 4 December 2021
Check for updates

(C) BMJ Publishing Group Limited 2021. No commercial re-use. See rights and permissions. Published by BMJ.

To cite: Chen J,
Hinton S. BMJ Case
Rep 2021;14:e247597.
doi:10.1136/bcr-2021-
247597

\section{DESCRIPTION}

A man in his 80 s with a background of low-grade B cell lymphoma, localised colorectal cancer in remission and hypertension was admitted for an Enterococcus urinary tract infection following instrumentation. He had no known drug allergies or previous exposure to antiarrhythmics. Examination demonstrated a new apical pansystolic murmur, which a transesophageal echocardiogram confirmed mitral valve vegetation suggestive of infective endocarditis. A peripherally inserted central catheter was inserted and he underwent a bioprosthetic mitral valve replacement on Day 0 with a short episode of postoperative atrial fibrillation (AF) requiring $4.4 \mathrm{~g}$ of amiodarone orally over 4 days (Days 6-10) before cessation.

On transfer to our rural hospital, he denied any respiratory symptoms and had a clear chest X-ray (CXR) (figure 1A). On Day 32, while continuing his parenteral antibody therapy, he developed AF, dyspnoea and hypoxia, which was presumed secondary to acute pulmonary oedema. He was given diuretics alongside $\mathrm{AF}$ treatment including amiodarone.

While his tachycardia resolved, his dyspnoea and hypoxia continued, with subsequent development of a dry cough. CXR on Day 34 (figure 1B) demonstrated increasing right-sided opacification with a concurrent rise in inflammatory markers. Due to concern for aspiration pneumonia, he was escalated to empirical piperacillin/tazobactam. The patient deteriorated with worsening hypoxia, delirium and CXR findings, hence he was escalated to meropenem, high dose trimethoprim/sulfamethoxazole and prednisolone to cover for multiresistant organisms, Pneumocystis pneumonia and inflammatory/ drug-related pneumonitis.

Numerous investigations including blood cultures, serial-induced sputum, respiratory virus including SARS-CoV-2, legionella and pneumococcus urinary antigen, serum galactomannan and vasculitis screen were unremarkable for an aetiology. Repeat echocardiogram on Day 36 did not demonstrate features of decompensated heart failure, with competent mitral valve with no features of regurgitation. CT chest/abdomen/pelvis on Day 37 (figure 2) demonstrated patchy groundglass airspace disease with subpleural consolidation predominantly of the right lung and no other overt concerning features including malignancy.

He continued to deteriorate both clinically and biochemically. Bronchoscopy was considered, however, was deemed too high risk. Consideration of amiodarone-induced interstitial pneumonitis was

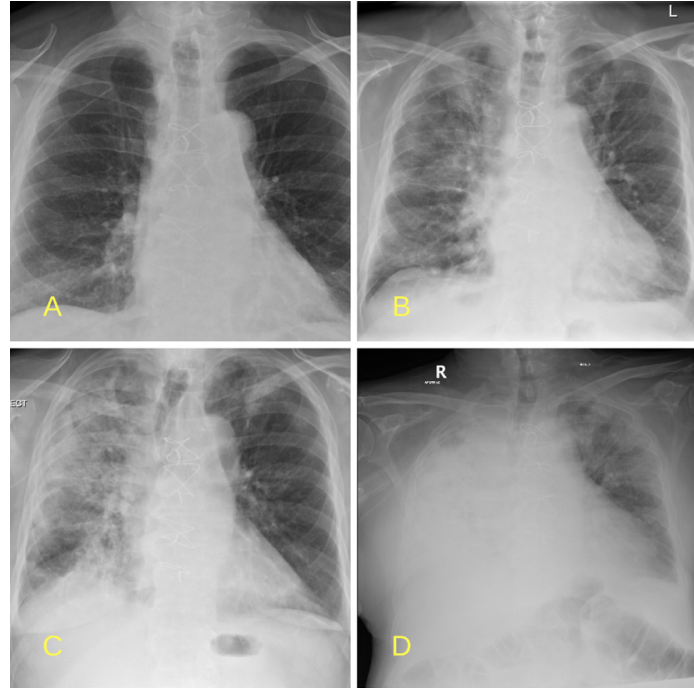

Figure 1 Chest X-ray series. (A) Day 23 with normal appearance on admission to our hospital. (B) Day 34 following commencement of amiodarone. (C) Day 46, after 16 days of exposure to amiodarone. (D) Day 51 with complete whiteout of the right lung.

considered and therefore amiodarone was ceased on Day 50, with the patient receiving $7.2 \mathrm{~g}$ of amiodarone over 18 days. Serial CXR on Days 46 and 51 (figure 1C,D) demonstrates rapid progressive opacification of the right lung with relative sparing of the left with resultant complete white out

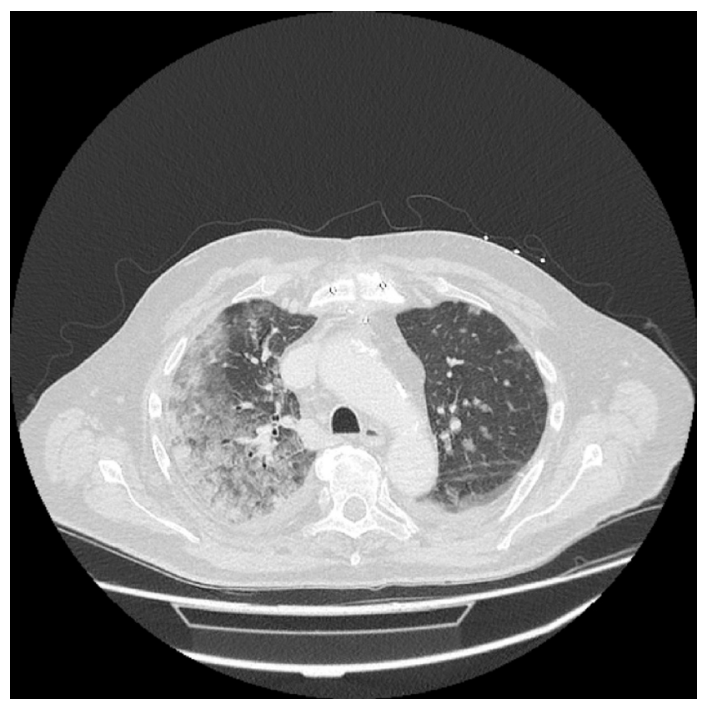

Figure 2 A-CT chest scan on Day 37-unilateral ground-glass opacities with subpleural predominantly of the right lung. 
of the right lung. Due to the rapid progression, clinical deterioration and the patient's family's wishes, he was transitioned to end of life care and passed away on Day 53.

A postmortem needle biopsy of the right lung was performed on Day 55. The histopathology noted a spectrum of changes including active alveolar damage with hyaline membrane formation, mild chronic interstitial inflammation, patchy alveolar fibrosis thickening and prominent interstitial fibrosis. Numerous foamy macrophages were seen within the alveoli with the presence of type II pneumocytes hyperplasia. This was consistent with amiodarone-induced interstitial pneumonia. No organism was cultured or identified on either biopsy or pleural fluid aspirate.

Amiodarone-induced interstitial pneumonitis is a recognised adverse drug reaction typically associated with prolonged amiodarone exposure. ${ }^{1}$ It typically presents with insidious onset non-productive dyspnoea and cough after 6-12 months

\section{Learning points}

- Amiodarone-induced interstitial pneumonitis can be acute and is not necessarily dose-dependent on amiodarone exposure.

- The presentation can be varied including unilateral pulmonary interstitial changes and should be considered a differential for any patients with respiratory symptoms on amiodarone. of therapy and bilateral chest infiltrates. ${ }^{1}$ However, this presentation can vary, and acute amiodarone interstitial pneumonitis has been recognised especially in the context of cardiothoracic surgery. It is rarer and more aggressive with typical presentation as acute respiratory distress syndrome and has associated high mortality. ${ }^{2}$ Understanding of the incidence, underlying risk factors and pathogenesis is poorly understood. Current management suggests cessation of amiodarone and supportive care. ${ }^{2}$

Contributors JC and SH were both involved in the clinical care for the patient. JC drafted the manuscript with $\mathrm{SH}$ supervision and revision input.

Funding The authors have not declared a specific grant for this research from any funding agency in the public, commercial or not-for-profit sectors.

Competing interests None declared.

Patient consent for publication Consent obtained from next of kin.

Provenance and peer review Not commissioned; externally peer reviewed.

Case reports provide a valuable learning resource for the scientific community and can indicate areas of interest for future research. They should not be used in isolation to guide treatment choices or public health policy.

\section{ORCID iD}

James Chen http://orcid.org/0000-0002-7665-5949

\section{REFERENCES}

1 Wolkove N, Baltzan M. Amiodarone pulmonary toxicity. Can Respir J 2009;16:43-8.

2 Feduska ET, Thoma BN, Torjman MC, et al. Acute amiodarone pulmonary toxicity. $J$ Cardiothorac Vasc Anesth 2021;35:1485-94.

Copyright 2021 BMJ Publishing Group. All rights reserved. For permission to reuse any of this content visit

https://www.bmj.com/company/products-services/rights-and-licensing/permissions/

BMJ Case Report Fellows may re-use this article for personal use and teaching without any further permission.

Become a Fellow of BMJ Case Reports today and you can:

- Submit as many cases as you like

- Enjoy fast sympathetic peer review and rapid publication of accepted articles

- Access all the published articles

Re-use any of the published material for personal use and teaching without further permission

Customer Service

If you have any further queries about your subscription, please contact our customer services team on +44 (0) 2071111105 or via email at support@bmj.com.

Visit casereports.bmj.com for more articles like this and to become a Fellow 